\title{
PENINGKATKAN PENGUASAAN MEMAHAMI OPERASI BILANGAN BULAT MELALUI TEHNIK PAIKEM THE POWER OF TWO SISWA SMP
}

\author{
Cahye \\ SMP Negeri 3 Kubu \\ Email: cahye3@gmail.com
}

\begin{abstract}
This research was aimed to find out the process of activities in an effort to improve mastery of understanding integer operations through the PAIKEM technique The Power Of Two (strength of two peoples) in class VII A Junior High School 3 Kubu. Mastery of understanding integer operations by students in mathematics learning is still low, so that the learning was unpleasant and uninteresting. Therefore, we need a learning technique that is able to improve mastery of understanding by students so that it can also improve learning outcomes. The method used is the method of discussion. Results of this study are indicated by an increase in mastery of understanding integer operating material by students in learning. In the first cycle of meeting 1 obtained $60.25 \%$, and meeting 2 obtained $62.73 \%$. In the second cycle meeting 1 obtained $79.87 \%$ and meeting 2 obtained $79.50 \%$ with the mastering category.
\end{abstract}

\section{Keywords: Mastery of understanding, PAIKEM Technique The Power Of Two}

\section{PENDAHULUAN}

Guru adalah sebagai tenaga pendidik propesional diharafkan dapat mengembangkan ilmu pengetahuan yang dimilikinya. Pengetahuan yang bersifat abstrak hendaknya dapat dituangkan dalam pengertian yang dapat dipahami. Belajar matematika erat kaitannya dalam kehidupan manusia sehari-hari. Akan tetapi penguasaan belajar matematika masih banyak dirasakan sulit oleh sebagian besar peserta didik, salah satunya adalah penguasaan memahami operasi bilangan bulat. Ini disebabkan karena belajar matematika materi operasi bilangan bulat banyak didominasi oleh pengenalan rumus-rumus serta konsepkonsep secara verbal. Menurut Rufini (2013: 22) menyebutkan bahwa penguasaan pembelajaran matematika yang diterapkan kepada peserta didik akan menghadapi kesulitan saat mereka diajar menggunakan rumus-rumus serta konsep-konsep tanpa ada perhatian yang cukup terhadap pemahaman peserta didik tersebut. Selain itu juga proses pembelajaran yang dilakukan hampir selalu berlangsung dengan guru yang menjadi pusat dari seluruh kegiatan di kelas.

Observasi awal di kelas VII A SMP Negeri 3 Kubu, menemukan bahwa penguasaan memahami materi operasi bilangan bulat masih banyak ditemukan bahwa peserta didik belum mampu dalam melakukan operasi hitung, pembuatan garis bilangan terutama dalam meletakkan bilangan bulat negatif disebelah kiri hanya ditulis bilangan bulatnya saja, tanda negatifnya tak ada, tidak kreatif dalam menentukan letak bilangan nol. Bahkan cara megang penggarispun masih kaku. Kemudian penunjukan arah panah dari operasi bilangan bulat masih banyak yang salah.

Kemudian juga ketidakmampuan peserta didik dalam memahami operasi bilangan bulat juga disebabkan oleh karena saat guru menjelaskan di depan kelas peserta didik kurang antusias dalam mengikuti pembelajaran, mereka lebih bersifat pasif, enggan, takut atau bahkan malu untuk 
mengemukakan pendapatnya, takut bahkan sibuk berbicara bersama temannya sehingga tidak memahami bagaimana cara membuat garis bilangan yang benar serta cara mengoprasikan bilangan bulat sesuai dengan rumus-rumus serta konsep-konsep yang sudah ada.

Oleh sebab itulah peneliti ingin berupaya agar proses belajar mengajar menjadi lebih aktif dari pembelajaran yang berpusat pada guru menjadi pembelajaran yang berpusat pada peserta didik dengan melakukan proses pembelajaran dari sekedar untuk tahu (learning to know) menjadi pembelajaran untuk berbuat (learning to do ). Berdasarkan uraian tersebut diatas, perlu diadakan suatu perbaikan yaitu penelitian tindakan kelas dengan judul " Upaya Meningkatkan Penguasaan Memahami Materi Operasi Bilangan Bulat Melalui Teknik PAIKEM The Power Of Two (kekuatan dua orang) di kelas VII A SMP Negeri 3 Kubu ".

Menurut Ausubel (dalam Rufini) penguasaan materi pembelajaran dapat diklarifikasikan kedalam dua dimensi. Dimensi pertama berhubungan dengan cara informasi atau materi pelajaran yang disajikan pada peserta didik. Dimensi kedua menyangkut cara bagaimana peserta didik mengaitkan informasi itu pada struktur kognitif yang telah ada. Struktur kognitif adalah fakta-fakta atau konsep-konsep yang telah dipelajari dan diingat oleh peserta didik.

Dari pendapat di atas dapat disimpulkan bahwa penguasaan belajar dalam penelitian ini adalah tingkat keberhasilan peserta didik dalam menguasai dan memahami materi operasi bilangan bulat saat proses pembelajaran berlangsung dalam bentuk skor nilai pengetahuan dan ketrampilan yang diperoleh peserta didik tiap-tiap siklus yang dilakukan melalui teknik PAIKEM The Power Of Two (kekuatan dua orang). PAIKEM dapat dikaji dari setiap kata yang ada padanya, yaitu aktif, inovatif, kreatif, efektif, dan menyenangkan. Artinya, pembelajaran ini dapat dijelaskan melalui 5 konsep pada prakteknya yang merupakan satu kesatuan yang utuh yang tak terpisahkan.

Hasil dari proses pembelajaran dapat dilihat dari beberapa bentuk seperti: perubahan tingkat penguasaan, pengetahuan, pemahaman konsep, keterampilan dan kecakapan, sikap serta aspek-aspek lain yang ada pada individu yang belajar. Menurut Bistari (2015: 159) " Untuk memperoleh hasil belajar yang optimal, seorang guru dituntut kreatif untuk menumbuhkan dan membangkitkan motivasi belajar peserta didik". Dalam hal ini peneliti memberikan tes latihan soal yang dilakukan peserta didik secara perorangan kemudian dilanjutkan dengan kerja berdua untuk memperoleh hasil yang diiginkan.

Menurut Yudhi Munadi ( 2010: 75), The power Of Two adalah berpikir berdua lebih memiliki kekuatan dibandingkan berpikir perorangan. Agar dapat menyampaikan sesuatu pendapat peserta didik belajar dengan lebih efisien dari rekannya daripada gurunya. Kegiatan ini menuntut semua orang mengambil tanggung jawab dan oleh karenanya melatih peserta didik dalam belajar mandiri dan saling ketergantungan.

Alat yang peneliti gunakan untuk menciptakan lingkungan pembelajaran menjadi hidup dan menyenangkan dalam penguasaan materi, peneliti menggunakan batang orden yang dilengkapi dengan kawat pengait agar mudah untuk menggantung nomor bilangan bulat positif dan negatif serta mudah untuk menggesernya dan juga menggunakan literasi matematika yang dirancang oleh peserta didik dalam bentuk gambar sebagai hasil dari operasi bilangan bulat. Ini menjadi menarik karena tiap pasangan akan berusaha untuk menguasai materi yang dipelajari.

\section{METODE}

Penelitian ini adalah Penelitian Tindakan Kelas (PTK). Subjek penelitian ini adalah peserta didik kelas VII A SMP Negeri 3 Kubu yang berjumlah 23 peserta terdiri dari 15 laki-laki dan 8 perempuan. Sedangkan objek penelitian ini adalah 
penguasaan memahami materi operasi bilangan bulat melalui tehnik PAIKEM The Fower Of Two ( kekuatan dua orang ). Penelitian ini dilaksanakan pada tanggal 14 Agustus sampai dengan tanggal 5 September Tahun Pelajaran 2018/2019.

Alat pengumpul data berupa lembar observasi diperoleh dari setiap siklus. Data observasi kemudian disajikan kedalam tabel dengan aspek diamati sebagai berikut: 1) Memperhatikan guru saat menjelaskan di depan kelas. 2) Mengajukan pertanyaan terhadap penjelasan yang kurang paham. 3) Dapat membuat garis bilangan dan kreatif dalam menentukan letak bilangan nol sesuai soal. 4) Pandai menggunakan penggaris saat membuat garis panah sebagai hasil jawaban dari soal. 5) Mau bekerja sama memecahkan masalah dalam pasangan (The Power Of Two). 6) Semangat mengikuti proses pembelajaran. 7) Menampakkan keceriaan dan selalu ingin mencoba lagi.

Tabel 1.

Observasi Penguasaan Memahami Operasi Bilangan Bulat

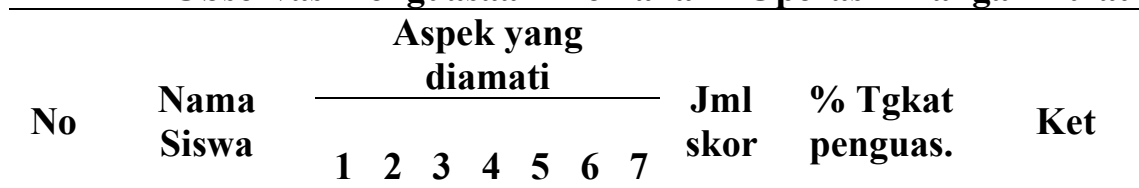

\begin{tabular}{l}
\hline 1 \\
\hline 2 \\
\hline 3 \\
\hline $\begin{array}{c}\text { \% Penguasaan memahami materi oleh } \\
\text { peserta didik. }\end{array}$ \\
\hline
\end{tabular}

- Jika indikator yang diamati dilakukan oleh peserta didik diberi skor 1

- Jika indikator yang diamati tidak dilakukan oleh peserta didik diberi skor 0 (nol)

- Skor maksimal $=7$, skor minimal $=0$

Nilai penguasaan dapat dihitung dengan rumus:

$\frac{\text { Skor perolehan }}{\text { Skor maksimum }} \times 100=$

Keterangan diisi dengan kriteria berdasarkan rentangan berikut :

Sangat baik $: 3,20-4,00(80-100)$ atau sangat menguasai

Baik $\quad: 2,80 \_3,19(70-79)$ atau menguasai

Cukup : :2,40_2,79(60-69) kurang menguasai

Kurang $\quad$ : kurang 2,40 ( kurang dari $60 \%$ ) tidak menguasai

Sumber: Kemendikbud (2013).

\section{HASIL DAN PEMBAHASAN}

Kegiatan yang dilakukan pada perencanaan adalah: (1) Menyiapkan kelas tempat penelitian. Selanjutnya menyiapkan rencana pelaksanaan pembelajaran (RPP), membuat soal tes bentuk essay, membuat LKS dengan operasi bilangan bulat penjumlahan dan pengurangan. merancang pembagian pasangan agar tidak terjadi penumpukan pasangan yang pintar saja, membuat lembar observasi, membuat catatan lapangan dan foto dokumentasi sebagai bukti, menentukan jadwal; dan (2) Peserta didik diperlihatkan gambar yang sudah dirancang sesuai RPP dan dibuat melalui media powerpoint, kemudian peserta didik diminta memberikan tanggapan mengenai gambar tersebut. Peneliti mempersiapkan alat yang digunakan berupa batang orden yang sudah dilengkapi pengait untuk menggantung nomor bilangan dan mudah untuk menggesernya.

Peserta didik dibagi dalam kelompok berpasangan. Setiap pasangan diberikan lembaran berupa gambar mobil dilengkapi dengan soal operasinya, setiap anggota pasangan bekerja masing-masing mengerjakan tugas sesuai dengan operasi yang ditunjukkan oleh gambar mobil itu. Selang beberapa waktu yang sudah 
ditentukan kemudian masing-masing pasangan mengerjakan bersama-sama membuat jawaban baru untuk soal yang sama. Terlihat beberapa peserta didik tidak bekerja sama dan hanya mengandalkan teman nya, ada juga bekerja secara individu, dan yang melakukan the power of two untuk bekerjasama dengan pasangan nya. Ada yang mau bertanya pada peneliti saat menemui kesulitan mengerjakan soal. Namun ada juga anggota pasangan yang sudah berani bertanya pada peneliti dan memang peserta tersebut memang sudah pandai matematika. Saat peneliti berkeliling memperhatikan aktivitas peserta didik, peneliti melihat hanya peserta didik yang bertanya saja yang semangat untuk belajar, berusaha menjawab dan melakukan kegiatan belajar seperti yang disarankan peneliti. Observer terus melakukan catatan lapangan terhadap aktivitas- aktivitas yang dilakukan oleh peserta didik selama pembelajaran berlangsung.

$\begin{array}{llr}\text { Selesai mengerjakan } & \text { lembar } \\ \text { pertanyaan tadi, tiap } & \text { pasangan } \\ \text { mempresentasikan } & \text { hasil diskusi }\end{array}$
pasangannya. Pasangan yang lain menyimak saat temannya maju ke depan kelas. Teknik PAIKEM The Power Of Two (kekuatan dua orang ) baru kelihatan sedikit. Mungkin cara ini belum terbiasa dilakukan. Kebiasaan mereka hanya suka nyontek atau menunggu hasil kerjaan temannya saja. Hari pertama kegiatan siklus 1 dimana upaya peneliti untuk meningkatkan penguasaan memahami materi operasi bilangan bulat di kelas VII A belum berhasil. Ini dapat peneliti lihat dari hasil tes diakhir kegiatan dan hasil observasi oleh observer, berikutnya Peneliti menutup pelajaran dengan mengucap salam.

Dari lembar observasi siklus I tingkat penguasaan memahami materi oleh peserta didik dalam pembelajaran juga telah menunjukkan peningkatan dari pertemuan 1 yaitu $60,25 \%$ menjadi $62,73 \%$, pada pertemuan 2, jadi terjadi peningkatan sebesar 2,48\% saja.

Penelitian ini belum dikatakan berhasil meningkat karena dari pertemuan 1 dan pertemuan 2 jumlah peserta didik yang tuntas baru mencapai 8 orang atau sebesar $34,78 \%$, peneliti memutuskan akan dilanjutkan pada siklus II.

Dari pelaksanaan siklus 2, diperoleh hasil belajar peserta didik (tes) diperoleh nilai rata-rata peserta didik sebesar 78,70 , peserta didik yang tuntas sebanyak 18 orang (78,26\%), peserta didik yang tidak tuntas sebanyak 5 orang $(21,74 \%)$ dengan nilai tertinggi 100 dan nilai terendah 30 .

Hasil observasi penguasaan memahami materi pada siklus II dari 79,87\% menjadi $79,50 \%$, peserta didik dalam pembelajaran menunjukkan kategori menguasai.

Tabel 1.

Hasil observasi penguasaan memahami materi oleh peserta didik

\begin{tabular}{lcccc}
\hline & \multicolumn{2}{c}{ Siklus 1 } & \multicolumn{2}{c}{ Siklus 2 } \\
\cline { 2 - 5 } & Pert 1 & Pert 2 & Pert 1 & Pert 2 \\
\hline $\begin{array}{l}\text { \% penguasaan } \\
\text { memahami materi }\end{array}$ & $60,25 \%$ & $62,73 \%$ & $79,87 \%$ & $79,50 \%$ \\
\hline
\end{tabular}




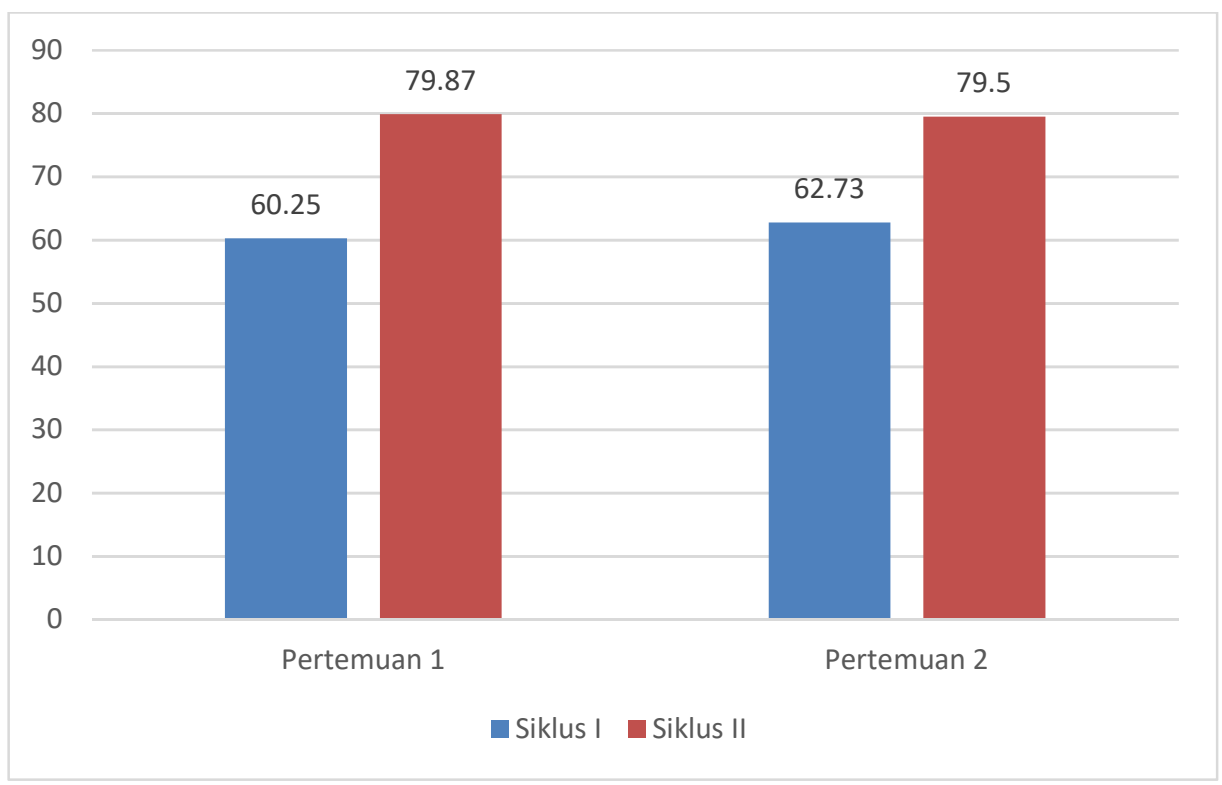

Gambar 1. Penguasaan Memahami materi oleh Peserta Didik

Pada tahap refleksi siklus 2, peneliti dan guru IPA SMP Negeri 3 Kubu sebagai observer yaitu Ibu Erni Melina Samosir, S.Pd berdiskusi untuk mengetahui tingkat keberhasilan dari tindakan yang telah dilakukan. Peneliti menemukan adanya peningkatan hasil belajar peserta didik terhadap penguasaan memahami materi operasi bilangan bulat di kelas VII A SMP Negeri 3 Kubu. Untuk itu peneliti dan observer menutup kegiatan pengambilan data sampai pada siklus II saja. Menurut Rufini (2013 :12) menyebutkan bahwa penelitian boleh dihentikan bila data yang diperoleh sudah mencapai sesuai indikator yang diinginkan. Tetapi proses pengamatan terhadap belajar tetap masih dilanjutkan untuk melihat tingkat penguasaan memahami materi operasi bilangan bulat melalui literasi matematika.

Ulangan harian adalah proses pembelajaran yang dilakukan diakhir kegiatan pembahasan seluruh materi sudah selesai. Tujuannya untuk mengetahui apakah materi yang diberikan kepada peserta didik dapat menerapkannya dan juga untuk melihat sejauh mana materi yang kita sampaikan kepada peserta didik dapat diterimanya.
Dilihat dari data yang diperoleh menunjukkan bahwa tingkat penguasaan memahami materi operasi bilangan bulat melalui tehnik PAIKEM The Power Of Two (kekuatan dua orang) menggunakan bantuan batang orden sebagai garis bilangan mengalami peningkatan oleh peserta didik kelas VII A SMP Negeri 3 kubu dalam kategori menguasai.

Pada pertemuan selanjutnya, peneliti melakukan pembelajaran menggunakan literasi matematika sebagai alat bantu pembelajaran lengkap dengan yel-yelnya oleh masing-masing kelompok pasangan yang terdiri dari 6 kelompok. Satu kelompok ada 4 peserta terdiri dari 2 pasangan. Keterlibatan peserta didik membuat proses belajar menjadi terasa semakin menarik. Peserta didik memperhatikan apersepsi yang diberikan. Kemudian menyampaikan informasi bahwa peserta didik akan diajar menggunakan literasi pembelajaran matematika materi operasi bilangan bulat. Kemaren mereka mencari berapa hasil dari operasinya sekarang mereka mencari bagaimana bentuk operasinya sehingga kegiatan yang dilakukan peserta semakin menarik perhatian dan semangat belajarpun semakin menyenangkan. 
Peserta didik mulai mengkondisikan dirinya dalam kelompoknya. Peneliti memberikan informasi bahwa waktu untuk mengerjakan membuat literasi adalah 10 menit, tiap anggota pasangan harus berusaha memahami dan menguasai materi yang sebelumnya yang telah mereka pelajari. Yang perlu diingat adalah sebelum mengerjakan secara berpasangan (The Power Of Two) peserta didik harus paham dengan soal yang dibuat. Beberapa peserta didik mulai bertanya kepada peneliti untuk menyakinkan bahwa keaktifan yang dilakukan adalah benar.

Saat dilakukan presentasi banyak peserta didik yang mau untuk kedepan menampilkan hasil jawaban dari hasil kerja pasangannya. Pembelajaran semakin lebih menarik dari sebelumnya, sehingga seluruh peserta dapat melihat keindahan dari media tersebut berupa gambar. Pasangan pertama menjawab media yang telah dibuat oleh kelompoknya dengan nama ikan literasi yaitu berapakah operasi yang menghasilkan $(-12)$.

Peserta didik mulai terbiasa menggunakan bantuan gambar literasi. Peneliti melakukan konfirmasi pada saat peserta didik menjawab pertanyaan yang kurang tepat saat mengoprasikan bilangan bulat. Menutup pelajaran dengan mengucap salam.

\section{SIMPULAN DAN SARAN}

\section{Simpulan}

Sesuai dengan rumusan masalah bahwa: (1) Pelaksanaan upaya meningkatkan penguasaan memahami materi operasi bilangan bulat melalui tehnik PAIKEM The Power Of Two (kekuatan dua orang) dapat terlaksana dengan baik, dimana peserta didik sangat mudah memahami rumus-rumus serta konsep-konsep menggunakan alat bantu yang digunakan sehingga dapat meningkatkan penguasaan memahami materi operasi bilangan bulat dan juga hasil belajar peserta didik kelas VII A SMP Negeri 3 Kubu dapat meningkat; (2) Hal ini ditunjukkan dengan peningkatan hasil belajar pada tiap siklus yang diperoleh dari belajar yang dicapai peserta didik pada siklus 1 yaitu 72,55 dengan persentase ketuntasan $65,22 \%$. Pada pertemuan ke 2 diperoleh nilai rata-rata 78,70 dengan persentase ketuntasan 78,26\%. Sedangkan untuk penguasaan memahami materi pada siklus I pertemuan 1 diperoleh 60,25\%, pertemuan ke 2 yaitu $62,73 \%$. Untuk siklus II, diperoleh hasil belajar dengan nilai ratarata sebesar 78,70 , peserta didik yang tuntas sebanyak 18 orang $(78,26 \%)$, peserta didik yang tidak tuntas sebanyak 5 orang $(21,74 \%)$ dengan nilai tertinggi 100 dan nilai terendah 30. Untuk penguasaan memahami materi pertemuan 1 adalah $79,87 \%$, pertemuan ke 2 diperoleh $79,50 \%$ dengan kategori menguasai dalam pembelajaran materi operasi bilangan bulat.

\section{Saran}

Berdasarkan simpulan diatas disarankan pada semua guru mata pelajaran agar dalam proses pembelajaran dapat memberikan perhatian terhadap pemahaman peserta didik sesuai dengan materi yang diajar agar dapat meningkatkan hasil dan penguasaan memahami materi. Setiap guru hendaknya dapat mengembangkan kreatifitas diri dan melakukan inovasi dalam meningkatkan kualitas pembelajaran. Variasi media dan kreatifitas guru dapat dikembangkan sesuai dengan keahlian guru masing-masing.

\section{DAFTAR REFERENSI}

Ausubel, (2011). The Psychology of Meaningful Verbal Learning. New York: Grune and Stratton.

Bistari, (2015). Mewujudkan Penelitian Tindakan Kelas. Pontianak: PT. Ekadaya Multi Inovasi

Kementrian Pendidikan dan Kebudayaan, 2013. Buku Guru Ilmu Pengetahuan Alam Kelas VIII. Jakarta: Kementrian Pendidikan dan Kebudayaan.

Rufini. (2013). Upaya Meningkatkan Penguasaan Materi Logaritma Melalui Model Pembelajaran Kooperatif Tipe Think Pair Share Pada Siswa Kelas X SMA Negeri I 
Sungai Raya. Jurnal Pendidikan Matematika Dan IPA Vol. 4 (1) hal 22 -35 .
Yudhi Munadi. (2010) Pembelajaran Aktif, Inovatif, Kreatif, Efektif, dan Menyenangkan. Jakarta: FITK. 